\title{
Improvement Physics 1 of Chemistry Learning Outcomes through Project- Based Learning Models (PjBL) Using Quiziz Online Learning Media
}

\author{
*Leony S. L. Purba ${ }^{\text {a) }}$, Meida E. Marpaung ${ }^{\text {b) }}$, Nelius Harefa ${ }^{\text {a) }}$, Anugrah Purba ${ }^{\text {a) }}$ \\ a) Program Studi Pendidikan Kimia/FKIP - Universitas Kristen Indonesia, Jakarta - Indonesia 13630 \\ b) Program Studi Pendidikan Kimia/FKIP - Universitas Tadulako, Palu - Indonesia 94119 \\ Received 30 June 2021, Revised 29 July 2021, Accepted 27 August 2021 \\ doi: 10.22487/j24775185.2021.v10.i3.pp203-207
}

\begin{abstract}
Improving cognitive abilities, namely learning outcomes, is one of the learning objectives. Learning outcomes can be enhanced by using creative, innovative learning models following the current curriculum, the 2013 revised curriculum. This study aims to determine whether there is an increase in physics chemistry 1 learning outcomes through the Project-Based Learning (PjBL) Learning Model using quiziz online learning media. Based on the normality and homogeneity test results, the data is typically distributed with the value of the normality test result of 0.638 (sig 0.05) and homogeneous with the homogeneity test result value of 0.144 (sig 0.05). The results of statistical analysis of research data using the paired t-test hypothesis test results obtained $t_{\text {count }}=17.685$ (sig 0.00) and $t_{\text {table }}=0.684$ (sig 0.05), it is concluded that there is an increase in learning outcomes in Physics Chemistry 1 through the project-based learning (PjBL) learning model using quiziz online learning media, because $t_{\text {count }}>t_{\text {table. }}$. A further test is the gain test to determine the level of improvement in learning outcomes results of the analysis using the gain test show a gain value of $42.51 \%$, with a medium category.
\end{abstract}

Keywords: Physics chemistry, project, learning outcomes

\section{Introduction}

Learning aims to develop all the potential that exists in students so that they become human beings who are characterized, competent, and literate. Teachers as educators can do various ways to achieve this. Innovation is the implementation of learning that teachers can implement is developing media and teaching materials and applying approaches, strategies, models, and learning methods appropriate to the characteristics of the material and classroom conditions. However, according to Rahayu \& Firmansyah (2018), most teachers had never prepared learning tools based on innovative learning models.

Innovative learning models vary greatly, depending on the needs and conditions of students and the learning environment. A teacher can develop the learning model to serve as a guideline to create a conducive learning atmosphere and neatly arrange for ongoing learning activities so that students achieve the learning objectives set (Indayaroh, 2018). Learning objectives are achieved when students can reach or exceed learning indicators. It can be seen from the average student's grades. The middle grade of a student in Indonesia is illustrated through the results of a national exam. According to the Ministry of Education and Culture in Junita \& Purba (2019), the average UN score in physics is 42.50 , biology 40.00 , mathematics 52.80 , and chemistry 30.0 . From these data, the lowest value is the value of chemistry subjects. Similar to universities, specifically in the UKI chemistry education study program. Chemistry values in pure chemistry courses, especially physics chemistry 1 , tend to below. Another thing happened at Medan state university. Based on research conducted by Siregar et al. (2019), the results of the student questionnaire were answered that students find it challenging to learn introductory chemistry, especially on the kinetics of redox and electrochemical chemistry, and radiochemistry.

Harefa et al. (2019) research results, the difference test between experimental group 1 and experimental group 2 student $t_{\text {count }}(5.411)>t_{\text {table }}$ (2.425) at Sig. 0.05, it concluded a difference in students' learning outcomes using project-based learning using Microsoft 365 handouts and sways. According to Redhana (2019), chemistry as one of the natural science disciplines contributed to developing 21 st-century skills. In efforts to build 21 st-century skills, educators can choose learning models that focus on a scientific approach. One learning model that focuses on a scientific method is the Project Based Learning ( $\mathrm{PjBL}$ ) learning model.

According to Jones et al. in Rahmawati et al. (2019), project-based learning $(\mathrm{PjBL})$ is a project

\footnotetext{
${ }^{*}$ Correspondence:

Leony S. L. Purba

e-mail: leony.purba@uki.ac.id

(c) 2021 the Author(s) retain the copyright of this article. This article is published under the terms of the Creative Commons AttributionNonCommercial-ShareAlike 4.0 International, which permits unrestricted non-commercial use, distribution, and reproduction in any medium, provided the original work is properly cited.
} 
learning model, which is expressed as a complex task based on challenging questions or problems to students so that they are involved in the design, problem-solving, decision making, and investigation. The results of Nurmi et al. (2020) research show that LKM-based PjBL has been developed effectively. The effectiveness of LKM based PjBL developed can be seen from the learning achievement test at the field test stage with an $\mathrm{n}$-gain score of 0.46 in the medium category. It is proven that using the $\mathrm{PjBL}$ model as a basis for developing MFIs is also very effective in improving learning outcomes (Safitri et al., 2019).

In addition to developing MFIs, other studies apply PjBL. Ambarita (2018), in the results of his research, stated increased chemistry learning outcomes in the high category, namely $74.2 \%$. Suheria et al. (2019), learning with the same type as $\mathrm{PjBL}$, model type course review HOORAY, and JIGSAW as much as being class was more considerable than control class that was $27.57>$ 19.47 and 44.2429 .18 obtained from the use of numbered head together in the study. Sinulaki (2019) showed that innovative project-based teaching materials effectively increase student competency.

Muryati's (2019) research results about improving chemistry teachers' ability to manage learning with the project-based learning model obtained results in cycles I, II, and III. The average achievement of chemistry teachers in cycles I and II in the project-based learning phase was $46.67 \%$ (medium category) and $79.33 \%$ (excellent type). There was a significant increase of $32.67 \%$ in the first to the second cycle. Based on Islami et al. (2020), the results of their cognitive score tests improved significantly after using the learning model PjBL in the classroom. Optimization of cognitive assessment in $\mathrm{PjBL}$ learning can be done using online assessment media. One of the online assessment media is a quiz.

According to the results of Purba's (2019) research, analysis of data obtained from pre-test and post-test showed an increase in the concentration of student learning through the use of evaluation of Quizizz learning in physics chemistry course I of 0.45 , with an interpretation of moderate improvement. The researcher using quizzes in national Olympic competition activities is also influential. The use of quizzes in this study makes learning assessment more effective, in other words, as a medium in capturing research data that will be needed so that it is not the focus of research. This research aims to improve physics and chemistry learning outcomes 1 through project-based learning (PjBL).

\section{Methods}

This study uses a quasi-experimental method with one group pre-test post-test design. The research design is presented in Table 1.

Table 1. Research design

\begin{tabular}{cccc}
\hline Group & Pre-test & Perlakuan & Post-test \\
\hline Experiment & $\mathrm{O}_{1}$ & $\mathrm{X}$ & $\mathrm{O}_{2}$ \\
\hline
\end{tabular}

This research was conducted at the Chemistry Education Study Program, Faculty of Teacher Training and Education (FKIP), Indonesian Christian University (UKI), East Jakarta. The time of the event is in the odd semester of the 2019/2020 school year. The population in this study were students of Chemistry Education FKIP-UKI with a sample of fifth-semester students. The sampling technique was carried out in this study with a nonprobability sampling technique with a purposive sampling method because the focus was on chemistry course 1 , which was scheduled for an odd semester.

The sample for this study consisted of 2018 students enrolled in chemistry course 1, comprising 18 female students and 7 male students. The subject of chemical equilibrium is the emphasis of this study's material.

Data collection techniques are ways to obtain data or data collection methods. The method used in this study is a quasi-experimental method where the experimental class is given a pre-test, treatment (learning with the PjBL model), post-test. The test instrument used for the pre-test and post-test was validated using expert judgment or an expert's opinion, namely the chemistry education lecturer in FKIP UKI.

The pre-test and post-test results were collected and analyzed using the paired T-test's hypothesis test. T-test results can be known if the value of Sig. (2tailed) $<0.05$, the hypothesis is proven, meaning $\mathrm{H}_{0}$ is rejected, and $\mathrm{Ha}$ is accepted. Where $\mathrm{H}_{0}$ shows, there is no significant effect of the Project-Based Learning $(\mathrm{PjBL})$ learning model on improving physics chemistry I learning outcomes. On the other hand, the data shows a substantial impact of the Project-Based Learning ( $\mathrm{PjBL}$ ) learning model on improving learning outcomes. Learning outcomes of physics and chemistry. Statistical hypothesis:

If $\mathrm{t}_{\text {table }}<\mathrm{t}_{\text {count, }}$ then Ho is accepted and $\mathrm{Ha}$ is rejected

If $t_{\text {table }}>t_{\text {count }}$ then Ho is rejected, and $\mathrm{Ha}$ is accepted

Furthermore, the researcher further conducted a gain-test to determine the percentage increase in student learning outcomes in physics and chemistry learning by applying the $\mathrm{PjBL}$ learning model. The gain score calculation aims to obtain different student learning outcomes.

$$
\% \mathrm{~g}=\frac{\text { Skor Posttest }- \text { Skor Pretest }}{\text { Skor ideal }- \text { Skor pretest }} \times 100 \%
$$

After getting the gain value from each student, next to calculate the gain value in the class, the trick is to find the average value of the course. After the gain value is known, interpret it using the gain index classification Table 2.

Table 2. Classification of gain indexes

\begin{tabular}{cc}
\hline Value $g$ & Interpertation \\
\hline $71-100$ & High \\
$31-70$ & Medium \\
$0-30$ & Low \\
\hline
\end{tabular}


The analysis requirements test is first performed before further hypothesis testing is carried out, namely the normality and homogeneity test using statistical software. The normality test uses the Shapiro-Wilk test, with the significance level of the test using $\alpha=0.05$. If the significance obtained $<\alpha$, then the sample does not come from a normally distributed population, and vice versa. A homogeneity test was performed using the Levene test, with a significant level of testing using $\alpha=0.05$ if the significance obtained $>\alpha$ then homogeneity data, and vice versa.

\section{Results and Discussion}

The research instruments originally compiled were 25 items. The number of questions declared valid by expert validators was 22 , and all valid questions were used in this study. A pre-test was conducted on the research sample using a valid pretest instrument. A pre-test is done through the Quizizz application. The results of the chemistry pretest data processing 1 on chemical equilibrium are presented in Table 3.

Table 3. Description of Pretest Data

\begin{tabular}{ccccc}
\hline N & Min. & Max. & Mean & $\begin{array}{c}\text { Std. } \\
\text { Deviation }\end{array}$ \\
\hline 25 & 40 & 65 & 50.60 & 7.12 \\
\hline
\end{tabular}

After a pre-test, students follow the Project Based Learning (PjBL) learning model. In this study, students work on projects per group, assembling teaching aids based on the chemical equilibrium theory.

At the end of learning, students take a post-test. Like the pre-test, the post-test is also done through the Quizizz application. The following are the results of processing chemistry post-test 1 data on chemical equilibrium in Table 4.

Student pre-test results are tested for homogeneity and homogeneity to determine the next parametric or non-parametric test. The normality test results, Shapiro-Wilk $(\alpha=0.05)$ using the statistics software were obtained and are presented in Table 5.

Table 4. Postest data description

\begin{tabular}{ccccc}
\hline N & Min. & Max. & Mean & $\begin{array}{c}\text { Std. } \\
\text { Deviation }\end{array}$ \\
\hline 25 & 55 & 90 & 71.60 & 8.50 \\
\hline
\end{tabular}

Table 5. Tests of normality

\begin{tabular}{ccc}
\hline Statistic & Df & Sig. \\
\hline 0.970 & 25 & 0.638 \\
\hline
\end{tabular}

Student pre-test results are tested for homogeneity and homogeneity to determine the next parametric or non-parametric test. The normality test results, Shapiro-Wilk $(\alpha=0.05)$ using the statistical software were obtained and are presented in Table 6.
Table 6. Test of homogeneity of variances

\begin{tabular}{cccc}
\hline Levene Statistic & df1 & df2 & Sig. \\
\hline 1.95 & 4 & 19 & 0.14 \\
\hline
\end{tabular}

Under the results in the table above, the homogeneity test results obtained 0.14 with a level of Sig. 0.05 . Because sig $0.144>$ Sig. 0.05 , the data for 25 study samples were declared homogeneous. The research results are normal and homogeneous, so researchers use the parametric test, the paired t-test. Test instruments, namely pre-test, and post-test are the same problem, but the arrangement of random questions. Furthermore, the paired t-test hypothesis test using statistics software shows the results for the pre-test and post-test data analysis results as presented in Table 7.

Table 7. Paired t-test hypothesis test result

\begin{tabular}{ccc}
\hline \multicolumn{2}{c}{ Pre-test-Post-test } & \\
\hline Mean & & 35.00 \\
Std. Deviation & & 9.89 \\
Std. Error Mean & & 1.98 \\
95\% Confidence Interval of the & Lower & 30.91 \\
Difference & Upper & 39.08 \\
$\mathrm{t}$ & & 17.68 \\
$\mathrm{df}$ & & 24 \\
Sig (2-tailed) & & 0.000 \\
\hline
\end{tabular}

Hypothesis Test Results Paired t-test results of $\mathrm{t}_{\text {count }}=17.685\left(\right.$ Sig 0.00) and $\mathrm{t}_{\text {table }}=0.684($ sig 0.05), it is concluded that there is an increase in learning outcomes in physics chemistry 1 through the projectbased learning $(\mathrm{PjBL})$ learning model using Quizizz (Quizizz, Inc.) online learning media because $t_{\text {count }}>$ $t_{\text {table. }}$. The further analysis uses the gain test, results obtained from pre-test and post-test data processing, the gain test results obtained by $42.51 \%$ in the medium category.

One learning model that applies active learning is project-based learning (Titu, 2015). Active learning can improve student learning outcomes. In this study, student learning activities using projectbased learning models improve student outcomes in physics and chemistry courses 1 . According to Faiqoh (2016), PjBL can influence students' critical thinking skills because at each stage. The advantage of $\mathrm{PjBL}$ is also one of the things that increased student learning outcomes in physics and chemistry courses I by using the project-based learning $(\mathrm{PjBL})$ learning model using Quizizz online learning media. According to Liawati et al. (2017), careful planning and longtime allocation are needed, especially in preparing project plans. It has become one of the causes of increasing learning outcomes in the medium category, not in the high category. Allocation of learning time with $\mathrm{PjBL}$ is only $4 \times 50$ minutes every week for each project to be carried out. This time limitation results in students' less than an optimal understanding of the topics presented. Most students gave positive responses and hoped that the problem-based learning 
strategy with a module-assisted cooperative approach could be continued and developed in learning physics chemistry 1.

Physical chemistry learning must be more creative and innovative to improve learning outcomes and in the high category significantly. Combining $\mathrm{PjBL}$ learning with online learning media can encourage student interest in learning (Purba et al., 2019; Purba et al., 2021). One online learning medium that can be used is Quizizz. This Quizizz application streamlines time and increases student interest in learning. But when viewed from the other side, for some students, the use of this application is not a maximum value. Students' nervousness causes the value that is not optimal, so they rush to work on the questions presented through the Quizizz application. The medium, not the high category, is also caused by the lack of student understanding of physics. That was revealed by several Chemistry Education students FKIP-UKI during an interview.

\section{Conclusions}

An increase in student learning outcomes in physics chemistry 1 through learning with the $\mathrm{PjBL}$ model using Quizizz online learning media $\left(\mathrm{t}_{\text {count }}=\right.$ $\left.17.685>\mathrm{t}_{\text {table }}=0.684\right)$, with a moderate increase category (42.51\%).

\section{Acknowledgments}

The authors gratitude goes to the lecturer at University Christian Indonesia (UKI) have helped the author in completing this research

\section{References}

Ambarita, B. (2018). Pengaruh model pembelajaran project based learning (PjBL) berbasis lesson study dengan macromedia flash terhadap peningkatan hasil belajar kimia siswa pada materi koloid kelas $X I$. Unpublished undergraduate thesis. Medan: Universitas Negeri Medan.

Sinulaki, B. R. (2018). Inovasi bahan ajar berbasis proyek pada pembelajaran kesetimbangan asambasa untuk meningkatkan kompetensi peserta didik. Unpublished undergraduate Thesis. Medan: Universitas Negeri Medan.

Safitri, N, R., Diah, A. W. M., \& Afadil, A (2019). The Differences on students' learning outcomes in grade $\mathrm{x}$ at sma negeri 1 parigi through the number head together (NHT) learning strategies and discussion on the topic of redox reaction. Jurnal Akademika Kimia, 8(2), 117-124.

Faiqoh, Z. B. A. (2016). Pengaruh model project based learning (PjBL) terhadap kemampuan berpikir kritis peserta didik pada materi pokok alat-alat optik kelas X MIA SMAN 1 Kebomas Gresik. Unpublished diploma Thesis. Malang: Universitas Negeri Malang.

Harefa, N., Silalahi, N. F. D., Sormin, E., Purba, L. S. L., \& Sumiyati. (2019). The difference of students' learning outcomes with project based learning using handout and sway Microsoft 365. Jurnal Pendidikan Kimia, 11(2), 24-30.
Indayaroh, N. (2018). Pengaruh model pembelajaran kooperatif tipe numbered heads together (NHT) terhadap motivasi dan hasil belajar fiqih peserta didik kelas $V$ MIN 9 Blitar tahun ajaran 2017/2018. Unpublished undergraduate thesis. Tulungagung: UIN Tulungagung.

Islami, D., Adlim, M., \& Hasan, M. (2020). Projectbased learning on water filtration experiment in high school chemistry subject. Journal of Physics: Conference Series $1460012082,1-6$.

Junita, Y., \& Purba, L. S. L. (2019). Peningkatan hasil belajar kimia siswa melalui model pembelajaran kooperatif tipe think pair share (TPS) di SMAN 92 Jakarta. Jurnal Dinamika Pendidikan, 12(1), 41-54.

Liawati, L., Handayani, S., \& Rahayu, D. L. (2017). Penerapan model pembelajaran project based learning $(\mathrm{Pjbl})$ pada kompetensi dasar melakukan dasar pengawetan pada olahan susu segar. Jurnal Edufortech, 2(2), 114-123.

Muryati. (2019). Meningkatkan kemampuan guru kimia dalam mengelola pembelajaran dengan model project based learning. Edudikara: Jurnal Pendidikan dan Pembelajaran, 4(3), 174-183.

Nurmi., Yunita, A., Yusri, R., \& Delyana, H. (2020). Efektivitas penggunaan lembar kerja mahasiswa berbasis project based learning (pjbl) terinetrasi ICT. Aksioma: Jurnal Program Studi Pendidikan Matematika, 9(4), 1018-1025.

Purba, L. S. L. (2019). Peningkatan konsentrasi belajar mahasiswa melalui pemanfaatan evaluasi pembelajaran Quizizz pada matakuliah kimia fisika I. Jurnal Dinamika Pendidikan, 12(1), 2939.

Purba, L. S. L., Sormin, E., Harefa, N., \& Sumiyati, S. (2019). Effectiveness of use of online games kahoot! chemical to improve student learning motivation. Jurnal Pendidikan Kimia, 11(2), 5766.

Purba, L. S. L., Harefa, N., Afridika, S., \& Savera, D. (2021). The differences of achievement of the national olympiad in chemistry at the public and private senior high school by utilizing Quizizz media. Jurnal Pendidikan Kimia, 13(1), 69-77.

Rahayu, G. D. S., \& Firmansyah, D. (2018). Pengembangan pembelajaran inovatif berbasis pendampingan bagi guru sekolah dasar. Jurnal Pengabdian kepada Masyarakat (Abdimas) IKIP Siliwangi, 1(1), 17-25.

Rahmawati, A., Fadiawati, N., \& Diawati, C. (2019). Analisis Keterampilan berkolaborasi siswa SMA pada pembelajaran berbasis proyek daur ulang minyak jelantah. Jurnal Pendidikan dan Pembelajaran Kimia (JPPK), 8(2), 430-443.

Redhana, I. W. (2019). Mengembangkan keterampilan abad ke-21 dalam pembelajaran Kimia. Jurnal Inovasi Pendidikan Kimia, 13(1), 2239-2252.

Siregar, L. F., Marpaung, D. N., \& Pongkendek, J. J. (2019). Diagnosis of basic chemistry II in 
student program study of the chemistry of FMIPA UNIMED. IOP Conference Series: Earth and Environmental Science, 343 012239, 1-5.

Suheria., Mustapa, K., \& Said, I. (2019). The application of cooperative learning model type review course hooray $(\mathrm{CRH})$ and jigsaw towards students' learning outcomes on class X SMA
Negeri 9 Palu in redox materials. Jurnal Akademika Kimia, 8(2), 65-71.

Titu, M. A. (2015). Penerapan model pembelajaran project based learning (PjBL) untuk meningkatkan kreativitas siswa pada materi konsep masalah ekonomi, Prosiding Seminar Nasional (176-186). Yogyakarta: Universitas Negeri Yogyakarta. 